Wellbeing in Developing Countries

Research Group

WeD Working Paper 09/49

\title{
Advancing Human Development: Values, Groups, Power and Conflict
}

Séverine Deneulin

July 2009 


\title{
Advancing human development: Values, groups, power and conflict
}

\section{Séverine Deneulin ${ }^{1}$}

\begin{abstract}
The question of values is central to the human development and capability approach. Yet, the capability literature says little about where values come from, how they are shaped and change. Exploring the dynamics of value formation and change is critical to advancing human development, for different sets of values lead to different sets of policies, and hence different capability outcomes. The paper argues that the human development and capability approach needs to pay greater attention to the different groups which construct the value frameworks from which people derive their values. This requires a more critical analysis of the power dynamics between groups. The paper proposes some analytical tools to examine the dynamics of value formation and its influence on policy. It concludes by discussing some ways in which the kinds of values which are necessary for advancing human development can be nurtured.
\end{abstract}

\section{Introduction}

In one of my first doctoral supervision meetings with Frances, there was a recurring comment pencilled throughout my abstract philosophical discussions on the capability approach: 'What does this mean for the real world?'. During subsequent doctoral supervisions, there were three points that she often emphasised. First, humans are not free individual agents who decide and act on the basis of their own reasoning. They are profoundly social and embedded into layers of complex social relationships. Human actions are never disconnected from the wider networks of social relations and institutions in which people are historically situated. In other words, human existence is one of belonging and this provides the condition for the exercise of freedom and agency. Another point that Frances was always quick to point out was that policy decisions were the results of power between different groups, whether political parties, social movements, international organizations, civil society organizations, global corporations, companies or business associations. A final point, linked to the latter, which she ensured was not neglected, was conflict. When one makes an individual decision about one’s life, there are often equally valuable claims which are conflicting. This is even more the case when making collective decisions. Collective

\footnotetext{
${ }^{1}$ University of Bath, UK. E-mail: s.deneulin@bath.ac.uk. I thank Judith Heyer, Nick Townsend and Peter Davis for helpful comments on an earlier draft. This is a paper which has been prepared for a conference in honour of Prof Frances Stewart, to take place in Oxford, 17-18 September 2009, and to be published in a Fetschrift.
} 
decision-making is fraught with conflict whose resolution through reasoning is not always straightforward.

This paper explores further these three points, and focuses on the analysis of the dynamics of value formation and its policy influence. It begins by discussing how values shape development policies and how the human development and capability approach conceives of the role of values in policy-making. The second section reviews some literature in psychology, sociology and philosophy, which offers some further insights into value formation and the policy influence of values. The third section puts forward some analytical tools that help better understand the dynamics of value change and its policy impact. It discusses especially the role of groups, which are the main drivers of value changes, and the power that these different groups command. It argues that policy change is often the result of conflict between groups which embed different value frameworks. The fourth section applies these analytical tools in the case of development policy-making in Costa Rica. The paper concludes by discussing the implications of taking into account groups, power and conflict in the formation of values for advancing human development.

\section{Values in human development}

Policies and values are inextricably linked. For example, slavery was abolished because some people came to endorse the value of equal dignity of all human beings, whatever the colour of their skin. Women were granted equal political, civil, economic and social rights with men because they refused to endorse the value of women's subordination to men and adopted instead the value of equality. Labour rights were introduced because workers campaigned for society to recognize the value of labour and dignity of workers. A better understanding of why people endorse certain values rather than others (e.g. the value of respect for tradition and obedience to authority vs. the value of equality and respect to all regardless of sex or skin colour), and of the processes that lead to value change, is crucial for advancing human development.

After decades of neglect due to the dominance of positivist economics on development economics and development policy, ${ }^{2}$ there has been a recent interest in exploring values and

\footnotetext{
${ }^{2}$ The works of Amartya Sen and the capability approach have played a significant role in bringing the ethical dimensions of economics to the fore, and as a consequence, in bringing ethics and the question of values to the heart of development economics, and development policies. See Sen (1987) and Alkire and Deneulin (2009a). See also the work of pioneer development ethicist Denis Goulet in Goulet (1996) and Gasper (2008)
} 
their influence on policy in development policy circles. In November 2008, the UK Department for International Development, in collaboration with the Foreign Office and the Ministry of Defence, organized a seminar entitled 'Values 2020: How will changing values and beliefs in the UK and key regions influence development and foreign policy in practice?'. ${ }^{3}$ The motivation for the seminar was the growing awareness that policies were not likely to succeed if they did not rely on, or respond to, people's values. Trying, for example, to make a country implement environmental policies while the majority of its population does not value environmental care, is bound to fail if people's values are not changed to include protection of the environment as a central value guiding their lives. Or, as the democratization literature has shown, it is a difficult enterprise to maintain a democratic regime in a country where its inhabitants do not uphold values traditionally associated with democracy such as tolerance, equality, fairness, respect for others and the rule of law. A clear understanding of people's values and how they change is thus essential for policies to succeed.

The seminar discussions, summarized in the report, led to some interesting conclusions for the purpose of the argument of this paper. Values were widely regarded as relating to how people should live and behave. It was recognized that values were not static but constantly respond to influences and economic and social processes. These latter were termed 'drivers of values'. The seminar identified several of them: global capitalism (materialism and conception of the good life linked to material wealth); environmentalism (shift in consumerism); class and inequality (one's situation of the economy shapes one's values in life); religion and secularism (religion may shape people's values); ethnicity and identity (how one identifies oneself as belonging to a specific group); immigration and the diaspora (immigration may change the dominant values of a society, and may also change the values of immigrants' countries of origin), and urbanization (cities change people's values).

In addition to recognizing values as being shaped by political, economic and social processes and vice-versa, a point that the seminar highlighted was that values were heterogeneous within societies, albeit with some degree of homogeneity. Speaking of British values or Muslim values in the aggregate as if every British or Muslim held the same values, masks a huge variety of views among the British or Muslim population. Yet, there is some relative homogeneity of values within a society so that one can state that there are values

\footnotetext{
${ }^{3}$ The event was organized by the Overseas Development Institute. A seminar report, not for public circulation, was drafted by Bhavna Sharma of ODI.
} 
which characterize British society, which are different from those which characterize, say, Nigeria or Japan.

That policy should rely on people's values in order to succeed - the starting concern of the seminar discussed above - has been one of the core arguments of the human development and capability approach. ${ }^{4}$ In his version of the capability approach, Amartya Sen has left the question of which precise values development policy should be based on, open. It only affirms that policies have to be judged in the space of capabilities or freedoms. ${ }^{5}$ It falls short of specifying 'valuable' capabilities beyond saying that policy ought to promote the 'capabilities of persons to lead the kind of lives they value - and have reason to value' (Sen, 1999: 18). However, while not being specific about valuable capabilities, the 'capabilities people have reason to choose and value' are, or should be, in line with the values implicit in the universal human rights declaration (Sen, 2004).

In her version of the capability approach, Martha Nussbaum has put the case for policies to promote an open-ended list of central human capabilities (Nussbaum, 2000). She entitles the second chapter of Women and Human Development 'In Defense of Universal Values'. She argues that certain 'very general values' such as 'the dignity of the person, the integrity of the body, basic political rights and liberties, basic economic opportunities and so forth’ (Nussbaum, 2000: 41) should be the universal norm to assess women's lives - and development - worldwide. Her central human capabilities reflect these values.

The secondary literature on the capability approach extends Sen and Nussbaum's analysis of values. Qizilbash (2002) reviews the different conceptualisations of advantage in development (primary goods, incomes, resources, capabilities, needs, etc.), and observes that all these share common values such as concern with human beings and the quality of human lives, universality (every human being should be able to live a good human life) and component pluralism (a good human life cannot be reduced to one dimension). Following the work of philosopher James Griffin, Qizilbash favours a specification of advantage in terms of values, and not in terms of the objects of values which, he argues, capabilities are. So it is not the specific 'capability to play' or 'capability to gain employment' (cf. Nussbaum's list) which should be promoted, but the value of 'enjoyment' or 'accomplishment' respectively,

\footnotetext{
${ }^{4}$ For the links between the capability approach and human development, see Alkire (2008) and Alkire and Deneulin (2009b).

${ }^{5}$ 'In the capability-based assessment of justice, individual claims are not to be assessed in terms of the resources or primary goods the persons respectively hold, but by the freedoms the actually enjoy to chose the lives that they have reason to value' (Sen, 1992: 81).
} 
contributions to which play or employment are only some specific instantiations. Capabilities are not values but ways in which more fundamental values are expressed.

In her book Valuing Freedoms Alkire (2002) similarly makes a careful distinction between values and capabilities, in contrast to Nussbaum which equates capabilities with values. Alkire separates the exercise of valuing from capabilities. Values are what allow people to prioritize capabilities. They are what enable people to judge what is important in their lives and what dimension of human wellbeing is more worthwhile to pursue in given contexts.

However, despite the centrality of values, the capability literature does not say much about the values which come into play during the valuation exercise. Alkire (2002) does not examine the reasons for which people value such dimensions of wellbeing and not others. In other words, she does not analyze the values, or value frameworks, which her respondents use in their value judgements. In the opening page of Valuing Freedoms, she writes that one of the beneficiaries of an Oxfam project in rural Pakistan 'values the income the rose project produces', and values the fact that her clothing smells nicely of roses and the inner peace that she derives from using the roses in religious ceremonies. Other respondents value the greater confidence that working in the rose project has given them.

Alkire then proceeds to discuss what people exercise value judgements about and how they can make such value judgments. She argues that people should exercise a value judgement upon a set of dimensions of human development (such as life, health and safety, knowledge and aesthetic experience, friendship, work and play, self-integration, selfexpression and transcendence). She proposes a series of principles which may help people make value judgements about which freedom in what dimension matters most in their particular context.

Thus, while emphasising the importance of values in development, what the human development and capability approach actually stresses is not as much values in themselves as the act of valuing, which it closely associates with the act of reasoning. Reasoning constitutes the core of democratic practice, a mechanism which Sen holds to be crucial in constructing people's values, and determining policy decisions (Sen, 1999a, b). For example, the practice of democracy might construct the value of solidarity, which will then serve as a criterion for the democratic reasoning exercise about what policy priorities should be taken. This may lead to policy decisions which extend public health services or improve the quality of stateprovided education. Inversely, democratic practice may construct other values such as the 
value of individual choice. This may lead to policy decisions which privatize public utilities and allow for greater private sector involvement in the health and education sectors.

Despite stressing the importance of people's values for development and policy (in terms of values shaping the reasoning process and outcomes), the human development and capability approach falls short of offering a detailed analysis of what values are, how they are formed and how they change. What values are used as criteria for value judgement? How come that certain countries use the value of 'individual choice' as criterion for policy decisions, while others use the value of 'solidarity'? How come that at one point in time, a country might have made decisions according to the criterion of solidarity and has now changed it for individual choice? An examination of some literature in psychology, sociology and philosophy may help answer these questions.

\section{Values in the wider social sciences}

Social psychology provides a more precise conceptualisation of values than the human development and capability approach does. Values 'are concepts or beliefs, pertain to desirable end-states or behaviours, transcend specific situations, guide selection or evaluation of behaviour and events, and are ordered by relative importance' (Schwartz, 1992: 6). ${ }^{6}$

From this definition, one can attribute two core characteristics to values: they refer to what is believed to be good (it is assumed here that something is desirable because it is thought to be good); and they guide human action. Research in social psychology has tried to identify which values guide people's behaviours and has found that there are some which guide people's actions universally, and that societies and individuals prioritize and express these universal values differently. On the basis of evidence from 20 countries, Schwartz (1992) singles out ten values which are universal but prioritized differently across societies and individuals: 1) self-direction (creativity, freedom, independence, curiosity, choosing one's goals); 2) stimulation (seeking an exciting life, taking risks, seeking novelty); 3) Hedonism (pleasure and enjoyment in life); 4) achievement (seeking success, ambition and influence); 5) power (authority, wealth, social recognition); 6) security (social order, harmony, family security, national security); 7) conformity (obedience, self-discipline, politeness, honouring parents); 8) tradition (respect for symbols and practices that represent the shared experience of groups); 9) universalism (social justice, equality, peace, beauty, protecting the environment);

\footnotetext{
${ }^{6}$ See Rohan (2000) for the various definitions of values in social psychology.
} 
and 10) benevolence (honesty, helpfulness, forgiveness, loyalty, responsibility). ${ }^{7}$ A society may prioritize the values of 'conformity' and 'tradition' more than the value of 'selfdirection' but another society might have the inverse priority. Or an individual may prioritize the value of conformity in relation to his in-laws but prioritize the value of stimulation in his relation to his employer.

One can object that the link between values and behaviour is not as straightforward as the above definition of values suggests. One might value honesty but behave in dishonest ways, e.g. by failing to pay a train fare because one knows that ticket controls will be very unlikely. Research in social psychology has widely documented the so-called 'value-action gap'. On the basis of experimental research and review of the literature, Verplanken and Holland (2002) have concluded that there is a strong link between value and behaviour but that a value is more likely to influence behaviour: if it is central to the conception of self (one might say that one values honesty but one may not identify oneself as an honest person); if the specific case calls on the value of honesty (being honest in paying one's train fare is not the same as being honest with one's spouse); and if there are not many other values which come into consideration (one might lie to one's children about the terminal disease of one's spouse in order to protect them).

Whereas psychology is more concerned with the individual than society, the discipline of sociology emphasises the role of social norms in the translation of values into behaviours. As in social psychology, values 'define what is considered important, worthwhile and desirable' (Giddens, 2004: 22), but sociology adds to this the importance of social norms, which are 'the rules of behaviour which reflect or embody a culture's values' (Giddens, 2004: 22). Giddens gives the contrasting examples of the values of achievement and hospitality. In some cultures, there are strong social norms which put pressure on people to be high professional achievers. Failing to be professionally successful might inflict on the person a sense of guilt, social disapproval or personal failure. Other cultures may have strong social norms regarding the values of hospitality and redistribution. Failing to honour guests adequately may result in a similar sense of guilt, social disapproval or personal failure.

Structuration theory has shown (Giddens, 1984) that there is a two-way relationship between structures and social norms on the one hand, and individual agency on the other. Individuals act within the constraints of certain social norms and structures, but these norms

\footnotetext{
${ }^{7}$ The value of spirituality (meaning and harmony through the transcendence of everyday reality) is a value which was found in some countries but not all the 20 countries studied by Schwartz.
} 
and structures are themselves changed by people's individual actions. ${ }^{8}$ For example, how Western societies value the institution of marriage has undergone radical changes over the last fifty years through the actions of individuals, such as those of feminist writers. A society's values, and its corresponding enforcing social norms, are thus not unchangeable. As the next section will illustrate, there are individuals, and the groups they form, which are agents of change, and have the power to change a society's core values. But why are values different across cultures, and why do they change? Some literature in political philosophy may give us some further insights.

Like sociologists, some political philosophers have stressed the links between values and social practices (Raz, 1999, 2003) - what sociologists called social norms. For example, values such as 'solidarity' or 'freedom' would be meaningless without the shared social practices which sustain them (taxation, distribution of benefits, freedom of expression, freedom of association, etc.). Values are what the philosopher Charles Taylor (1995) calls 'irreducibly social goods'. They inhere in social relationships, whether in specific groups, such as the values which are sustained by the social practices of a family, trade union or a women's institute group, or wider communities, such as the values which are sustained by the social practices of a religious community or by those bound by a common history or language.

There are many groups from which people derive their values. One of the first groups that humans are born into is that of a family, which is itself moulded by many other groups. The child grows up endorsing the values embedded in the social practices which surround him or her - even the language that one learns is a social practice which contains certain values such as about gender relations and respect for elders and people in authority. The social practices of the family themselves may be influenced by other groups such as religious groups and their view of what constitutes a 'family'. The child may also endorse the values of the education system which contains its own distinctive set of practices and values. In addition to schools, the media are also an important influence on people's values. One can already foresee here that belonging to multiple groups or communities, with their respective ordering of values, may lead to situations of conflict between values.

Unlike sociology, which limits itself to analysing the social influences on people's values, philosophy addresses the issue of morality, and provides a discussion about the 'goodness' of values, and whether some expressions of values are better than others. It

\footnotetext{
${ }^{8}$ As Marx famously claimed 'Men [sic] make their own history but not in circumstances of their own choosing.'
} 
analyzes e.g. whether societies should uphold the value 'achievement' more than that of 'solidarity', or whether expressing the value of 'achievement' in terms of social status and competition is more, or less, desirable than expressing it through e.g. good craftsmanship. In other words, philosophy examines the moral claims which underpin a society's core values and social norms.

There are many ethical theories which each leads to different conclusions or answers to the question 'What should one do?' or 'How should one live?' (to name some major ethical theories: Kantian ethics, Aristotelian ethics, and utilitarianism). The same ethical or moral theory may also have different interpretations. What is perceived as 'good' is hence constantly debated across individuals and changing over time, and so are the values and social practices which support them. For example, architecture is a social practice which expresses a society's aesthetic value and perception of beauty. What is of aesthetic value has obviously changed throughout the centuries because the idea of the good, in this case beauty, remains contested. Laws against the unfair treatment of women represent another social practice which has changed over time because society has come to understand equality in different ways following a change in the conception of what a 'good life' (for women) should be about.

These insights from psychology, sociology and philosophy - that values are connected to what people perceive as good, that there are universal values which societies and individuals prioritize differently, and that people draw their values from the various groups to which they belong - help us answer some questions that the human development and capability approach had left unanswered. It also helps us to understand better how values are formed and change. The next section examines further the dynamics of value change within the context of human development policy.

\section{Policy and the dynamics of value change}

Analysing the dynamics of value formation and change is central for advancing human development, for there are values which are more conducive to human development policies than others. For example, Kasser and Kanner (2004) document the negative impact of materialistic values on people's wellbeing and human development. Nurturing the 'right' kinds of values, or at least ensuring that some values are prioritized instead of others, is therefore essential to promoting human flourishing. This section analyzes two core ingredients of the interaction between the dynamics of value change and policy: groups as 'drivers of values' (what structuration theory referred to as the 'agency/structure' dynamics); 
and the power that these groups command in society, what often leads to situations of conflict.

\section{Groups as 'drivers of values'}

In a study on group behaviour and development, Stewart (2002) examined the dynamic interaction between the macro-environment, groups and development thinking. She argued that the mode of functioning of groups, whether groups tend to operate on a 'power/control', 'quasi-market' or 'cooperative' basis (Heyer, Thorp and Stewart, 2002), was greatly influenced by their social environment. Although she did not explore the extent to which groups in turn affect the macro-environment, her analysis gives us some insights.

She alludes to the importance of "claims groups" 9 in challenging prevailing social norms and the social order, and the distribution of assets in society, such as trade unions in $19^{\text {th }}$ century Europe or the suffragette movement. Other groups whose influence in shaping the macro-environment Stewart (2002) underlines are international financial institutions. She also notes that these groups have often been met with opposition and that the resulting social environment, and its characteristic norms and distribution of assets and benefits, is often the outcome of groups' power struggles.

She makes a similar argument in an article on 'Groups and Capabilities' (Stewart, 2005) where she emphasizes the importance of groups in human development, not only in directly promoting human freedoms through collective action (such as credit union groups offering better economic opportunities to the marginalized) but also in shaping what people value. In that respect, she notes that some groups may shape people's values in ways which might not be conducive to human development, e.g. groups which make people value respect for 'national' security over respect for human life, as in the case of some nationalistic groups.

These groups can be seen as 'drivers of values', or agents of value change. To recall, the DFID seminar discussed in the first section included among these drivers of values: the global capitalist economic system, environmentalism, class, religion, ethnicity, and urbanization. But beyond these drivers of values are certain powerful groups. Global capitalism is a system sustained by groups of people, such as multi-national companies, international financial institutions and most fundamentally by academic groups which practise

\footnotetext{
${ }^{9}$ Heyer et al. (2002) have attributed three functions to groups: 1) Overcoming market failures; 2) Claims functions, which 'arise where one of the purposes of the group is to advance the claims of its members to power and/or resources'; and 3) Pro-bono functions, which 'seek to alter the distribution of benefits within society, but [...] are directed mainly towards individuals outside the group [...].' (Heyer et al., 2002: 5-7).
} 
a certain type of economic theory. ${ }^{10}$ Similarly environmentalism is driven by environmental groups, by 'claims groups', which are trying to confront other groups which sustain other values, such as the prioritization of economic profits over environmental care. Urbanization changes people's values when they migrate to the cities, because cities are dominated by groups which uphold different values, or a different prioritization of values, than the dominant groups in rural areas.

This analysis of groups as agents of value change has remained absent from the human development and capability approach literature so far. There is a lot of talk about democracy as an important space where people reason on the basis of their values and where values are constructed, but there is little on the many groups which inhabit the democratic space and which construct people's values too, groups like religious communities, the education system, global corporations or the media. When Alkire (2002) mentioned that women in a Pakistani village valued the rose project because they could use them in religious ceremonies, she implicitly made the claim that religion was a significant source of values in people's lives. The human development and capability approach would need a more careful analysis of the relational spaces which shape people's values, and the groups which dominate them.

In a critique of the individualism of the capability approach, Evans (2002) cites the empires of Coca-Cola and MTV as shaping people's values and what they consider as 'valuable'. Sandel (2005) discusses how market practices and commercial pressures may corrupt civic institutions. ${ }^{11}$ When commercial advertising is used to finance education, it risks introducing a consumer attitude among students. Similarly for the health sector, seeing medication as a market product to boost companies' profits damages people’s perception of health care as public good. When the logic of markets and marketing is introduced into democratic institutions, their underlining civic values might be under threat. As he puts it:

When government leans too heavily on the borrowed appeal of cartoon characters and cutting-edge ads, it may boost its approval ratings but squander the dignity and authority of the public realm. And without a public realm in good repair, democratic citizens have little hope of directing the market forces and commercial pressures that quicken by the day and shape our lives in untold ways. (Sandel, 2005: 80)

Thus, a value-based approach to development, which the human development and capability approach is, needs to include an analysis of the groups or communities which foster or nurture

\footnotetext{
${ }^{10}$ For an analysis of how academic ideas, such as freedom as non-interference and other assumptions of neoclassical economic theory, gain policy influence, see Alkire and Ritchie (2007).

${ }^{11}$ He also discusses this theme in his Reith Lectures on BBC radio in June 2009. The lectures can be listened at www.bbc.co.uk/radio4/reith/.
} 
certain kinds of values. But there is another point that has to be taken into consideration: that value change is often the result of conflict between conflicting groups.

\section{Power and conflict}

Changing the prevailing values in a given society is often confrontational, for it entails direct opposition to the dominant groups which promote, and have an interest in promoting, these values. ${ }^{12}$ Power - and its frequent consequence, conflict, whether overt or hidden - lies at the core of agency and structural change (Giddens, 1984; Lukes, 2005). The French Revolution and American Civil Rights movement are good examples of this.

Eighteenth century France was characterized by a well-ordered society divided between the aristocracy and landless peasants. The prevailing values of French society at the time were that of respect for authority and tradition. These values were mainly promoted by two powerful groups which had an interest in maintaining that prioritization of values, the King and his entourage of aristocratic landlords, and the Catholic Church which had a strong association with the monarchy and aristocracy. ${ }^{13}$ The change towards a social order where the values of 'solidarity, fraternity and liberty' prevailed was accompanied by massive power struggles and conflicts.

The civil rights movement in the United States is another example of this. The 'good society' as being one in which blacks and whites were segregated because of a God-given social order was being put in question by groups of blacks (and some whites). This entailed conflict between different groups with competing visions of the good society, and hence competing value systems or frameworks. One group privileged, referring to Schwartz's typology of values, 'tradition' and 'conformity', the other privileged 'universality' and 'benevolence'. The values upon which policies were based in the United States in the 1970s were the direct outcomes of that power struggle between conflicting groups with competing value frameworks or value prioritization.

Other countries which have known similar conflicts between groups with competing visions of the good society and values experienced less fortunate outcomes in terms of human development. Guatemala and El Salvador are two countries which have been engulfed in

\footnotetext{
${ }^{12}$ For an analysis of how groups maintain inequality over time and exclude others from access to resources and opportunities, see Tilly (1998).

${ }^{13}$ For an analysis of such 'dynamics of contention' and the mechanisms through which groups are successful in changing the existing social order, including a detailed analysis of the French Revolution and the American Civil Rights movement, see McAdam, Tarrow and Tilly (2001).
} 
conflict between groups of landowners and landless farmers during the 1970s and 1980s, each one trying to impose their own values and vision of society. After nearly two decades of neoliberal policies in El Salvador, and a policy scene dominated by the landed elite and business class, the leader of the group which campaigned for land rights in the 1980s has recently come peacefully to power through democratic elections, signalling a probable change in the dominant values which underpin policy-making in El Salvador. ${ }^{14}$ Guatemala remains in contrast dominated by the whites and mestizos, leaving nearly half of its population marginalized and in conditions of acute poverty. ${ }^{15}$

The promotion of human freedoms is often not a peaceful enterprise. In a paper which provides a sociological reading of the capability approach, Feldman and Gellert (2006) write:

The welfare states, which perhaps come closer to providing for the capability(ies) that Sen and Nussbaum advocate, did not emerge in the abstract world in which people decided to 'assign responsibilities' to institutions that promoted social welfare programmes (Nussbaum, 2004: 15). Rather, welfare states were historically produced in Western Europe and North America in the early decades of the twentieth century through struggle and negotiation by working-class and women's movements. (Feldman and Gellert, 2006: 429)

But value changes need not always be the result of violent conflict and power struggles. Conflict may be hidden. This is especially the case regarding changes in values brought about by capitalism and global markets. In the Challenge of Affluence, Avner Offer (2006) provides a history of the changes that a mass consumption society has brought about. He argues that affluence is driven by novelty, or in other words, that a consumerist capitalist system has made a priority of the value of 'stimulation' (to refer to Schwartz's classification), leading people to want new things all the time. This constant search for novelty, made possible by expanding consumer choices, nurtures impatience, and impatience, Offer concludes, undermines human wellbeing (through, among others, increased addictions, levels of depression, family breakdowns and increased stress). He presses for the values of 'service to others, sense of humility and proportion' to replace those of 'self-interest, power, dominance, status’ (Offer, 2006: 371).

Consumerism is also changing people's values in developing countries. Research conducted by the ESRC Wellbeing in Developing Countries group (WeD, 2007) reported that poor households in rural areas in Thailand favoured humility over attaining status through job achievement or consumption of goods, while households in urban areas favoured gaining

\footnotetext{
${ }^{14}$ For an historical account of political power struggles in El Salvador, see Lauria-Santiago (2004).

${ }^{15}$ For a discussion of policy-making in Guatemala, see Sieder (2008).
} 
status and adopting a high consumerist lifestyle. This conflict of values was very apparent when urban migrants came back to their villages.

To sum up, the human development and capability approach needs to provide, in addition to an evaluative framework for states of affairs - the capability space, an analysis of the dynamics of value formation, of the different groups which shape these values, of the degree of power they command, and their consequent influence on policy. The next section examines the dynamics of group interaction, values and policies in the case of Costa Rica.

\section{Values and policies in Costa Rica}

Costa Rica has been known in development studies as a 'human development success story'. The country has achieved high levels of human development, with education and health indicators similar to those of industrialized nations, despite relatively low economic resources (Mesa-Lago 2000). The policies that enabled these achievements did not emerge from a normative vacuum but rested on certain values that were the outcome of a certain configuration of groups and the power they had. This section discusses four distinctive periods in Costa Rica's history in the light of the above analysis of the dynamics of value change, group interaction and policies. ${ }^{16}$

A first set of policies that played a crucial role in Costa Rica's development path was introduced at the end of the $19^{\text {th }}$ century. In 1886, the Costa Rican Constitution declared primary education free and compulsory for both sexes, and sanctions were imposed on parents who did not comply. The impact of the policy was dramatic and illiteracy fell sharply. The government's decision to promote universal primary education was motivated by two factors (Ameringer, 1982). First, the government endorsed the values of liberal capitalism and saw education as necessary to build a skilled workforce that would lead the country to a higher path of industrialization and economic development. Second, the government was committed to the values of secularism and a strong church-state separation. The banning of religious schools, which led to a state-control of the education system, was a means to protect education from the power of religion which was perceived as an enemy of reason and freedom of thought.

The second significant period in explaining Costa Rica's human development success was the 1940s decade. While the values of liberalism and secularism prevailed in late $19^{\text {th }}$ century, or at least prevailed among the group which held political power, these values were

\footnotetext{
${ }^{16}$ This section is drawn from material in Deneulin (2005, 2006).
} 
tested after the First World War. The country experienced economic and social collapse due to the sharp fall of coffee prices, Costa Rica's main export. Laissez-faire policies did not work to re-establish economic and social stability. A political party was created in the 1920s around the values of social democracy which prompted the government to undertake a range of social policies never conducted before, such as school meals. This path of social reforms took another turn with the election of Rafael Calderón Guardia in 1940. He introduced a social security scheme, which incorporated social insurance and social welfare programmes for the poorest. He also introduced other social guarantees, such as an eight-hour working day, a minimum wage, protection against arbitrary dismissal, and the right for workers to organize.

The reasons for such policies were two-fold (Ameringer, 1982; Wilson, 1998). One lay in the person of Calderón himself. He was a paediatrician deeply inspired by his experience as a medical student in Belgium, where he encountered the Social Doctrine of the Catholic Church and as a doctor in the poor suburbs of San José. Another reason lies in the political context of the time and the group dynamics. A coalition between the Communist Party and the Catholic Church was able to overpower the elite opposition to the social reforms. (The context considerably changed after the Second World War where strong values of anti-communism characterized the Catholic Church.)

A third decisive period was that of the post-war decades. Again the policies that Costa Rica took were strongly connected to the values that dominant groups held. In 1949, another President, José Figueres introduced compulsory secondary education, making both primary and secondary education free and state-financed. Food and clothing for poor students were provided by the state and adult education programmes were organized for those left out by the educational system. Figueres also introduced a law that allocated six per cent of GDP each year to public expenditures in education. He nationalized the banking system, abolished the army and imposed a wealth tax. These measures allowed the state to plan economic development, and they also led to a political weakening of the coffee elite. By weakening the power of the coffee elite, and building the 'state entrepreneur', Figueres determined the subsequent conditions for the economic and social development of the country (Ameringer, 1982; Mesa-Lago, 2000). His party, the Partido de Liberación Nacional (PLN), became the majority party that Costa Ricans voted for during the entire post-war period. Among the policies implemented were education policies, which further improved child and adult education and increased rural educational coverage, and an expansion of the health system. A special health programme, involving a network of health centres and mobile clinics, was established for those living in rural areas. This emphasis on primary healthcare led to 
significant improvement in health (Garnier et al. 1997). These policies relied on the core value of solidarity - that no-one should be in want - and on the belief that the state was the best keeper of this value - not private initiative.

In these three key periods for human development policy in Costa Rica, a few 'drivers of values', and their constitutive groups, can be highlighted. There is the bourgeoisie and its values of secularism and liberalism. Those who held political power in Costa Rica in late $19^{\text {th }}$ century were formed in that community. Religious communities can be another powerful 'driver of values'. There was the influence of religion on Calderón in his introduction of radical social reforms. One has to note however that religious communities are not homogenous and can form people in different values in time and space. For example, the Catholic Church of Costa Rica in the first half of the $20^{\text {th }}$ century was 'progressive' and formed people in the values of solidarity with the poor and advancing labour rights. This was not the case in $19^{\text {th }}$ century Costa Rica or in neighbouring Central American countries during most of the $20^{\text {th }}$ century. In these countries, the Church was allied with the elite and the military and was promoting among the faithful the values of obedience to authority.

The other influential Costa Rican President, José Figueres, was also formed by socialist groups. His biographer (Ameringer, 1978) reports that when Figueres went to study engineering in the United States, he did not attend lectures but instead spent his time in libraries reading about socialist theories of Charles Fourier and Saint-Simon. In addition to intellectual movements, political parties can be important places where the values necessary for advancing human development can be nurtured. The Partido de Liberación Nacional had a great role to play in shaping Costa Rican society around social democratic values. A political party, and its core values, can itself be influenced by other groups such as trade unions. Sanchez (2005) emphasizes that, in addition to the PLN, the trade unions of public sector employees were key in expanding the welfare state in Costa Rica.

The fourth significant period for human development in Costa Rica was the decade of the 1980s, which saw a fragmentation of the democratic consensus around the value of statesponsored solidarity in favour of the value of freedom seen as non-state interference. The social democratic model underwent a profound crisis in 1980-2 due to the oil crisis and the subsequent rise in interest rates. The Costa Rican economy no longer benefited from low interest loans from international banks to finance its welfare institutions. Its external debt increased sharply, GDP per capita fell, unemployment doubled, inflation soared, real wages contracted, poverty increased. Drastic structural adjustment policies were needed to deal with 
the crisis. The World Bank, and USAID, pressed the Costa Rican government to reduce its protectionism and increase the share of the private sector in the economy (Clark, 2001).

The crisis of the 1980s introduced a structural change in the macro-environment from which individuals draw their values. This brought an ideological change inside the PLN's own ranks, introducing a breach in the PLN's long socio-democratic tradition. The PLN became a party which supported greater private sector participation in the economy and liberalization of markets. The banks which had been nationalized in the late 1940s were privatized in 2002. The pension and health systems have also been progressively privatized since the 1990s. These changes have had considerable consequences for human development outcomes. While Costa Ricans still enjoy a better quality of life than their other Latin American counterparts, inequality is rising at a worrying rate (Estado de la Nación, 2008).

Rovira Mas (2004) talks about a 'new style of development', no longer based on the values of social democracy and solidarity but of market liberalism. He argues that this new style is the result of historic struggles between groups. Among them, he highlights the group of economists trained in neo-classical economics, the international financial institutions, and the Costa Rican political parties which have chosen to endorse the dominant values held by these groups. However, there are groups which are resisting the policies implemented by these dominant groups. The most striking example of this has been the popular protests throughout Costa Rica in 2000, formed by a coalition of trade unions, student organizations and many popular organizations, to prevent the privatization of the telecommunication company, which they saw as symbol of Costa Rica’s social democratic heritage.

\section{Conclusion}

In her analysis of groups in the capability approach, Stewart (2005) concluded that: 'Given their importance in determining whether people lead good lives (i.e. adopt valuable capabilities) it is important to support groups that encourage valuable capabilities as against those that do the opposite. The implication of this, is that priority should be given to researching group capabilities from a conceptual, empirical and policy perspective' (p. 199). This is what this paper has tried to do, to offer an analysis of the dynamics of value change and its impact on policy, within the context of the human development and capability approach. This requires careful attention to the groups from which individuals draw their values, and the respective power they command. This also includes acknowledging the reality of conflict as a positive force for social change.

Today, consumerism or a capitalistic economic order based on mass consumption is 
no doubt one of the major drivers of values shaping policies in the world; witness the lack of strong political action toward climate change, economic arguments seeming always to be more valued than environmental ones. But this observation does not lend itself to the fatalistic conclusion that nothing can be done about the power of unfettered global markets in shaping people's lives and what they value. There are other groups which shape what people value in other directions. I have named religious groups as important groups where people are formed in certain values and which can counteract the dominant values carried by a global capitalist system. Trade unions, environmental groups, and political pressure groups can be other groups where other values can be nurtured.

Advancing human development rests on a certain class of values. So far, writings on the human development and capability approach have neglected the importance of nurturing the kind of values which are conducive to human development and a more just social order. The paper has emphasized the key importance of the formative role of groups in shaping people's values in certain ways. The Human Development and Capability Association, the Human Development Report Office, and universities which are teaching human development in their curriculum, can be such formative groups or communities in shaping people around the values that are necessary for promoting social justice and human flourishing. Whether these groups can challenge the power of other groups which promote values which are at odds with human flourishing - such as values related to a consumerism and materialism- is a matter of perseverance and hope.

\section{References}

Alkire, Sabina (2002), Valuing Freedoms, Oxford University Press (2008), 'Using the Capability Approach: Prospective and Evaluative Analyses', in S. Alkire, M. Qizilbash and F. Comim (eds) (2008), The Capability Approach: Concepts, Measures and Applications, Cambridge University Press

Alkire, Sabina and Angus Ritchie (2007), 'Winning ideas: Lessons from free-market economics', OPHI Working Paper 6, at www.ophi.org.uk

Alkire, S. and S. Deneulin (2009a), 'The Normative Foundations of Development', in S. Deneulin with L. Shahani (eds), An Introduction to the Human Development and Capability Approach, London: Earthscan (2009b), 'The Human Development and Capability Approach’, in S. Deneulin with L. Shahani (eds), An Introduction to the Human Development and Capability Approach, London: Earthscan

Ameringer, Ch. (1978), Don Pepe: A Political Biography of José Figueres of Costa Rica, Albuquerque:

University of New Mexico Press

(1982), Democracy in Costa Rica, New York: Praeger Publishers

Clarke, Mary A. (2001), Gradual Economic Reform in Latin America, New York: SUNY Press 
Deneulin, Séverine (2005), 'Development as Freedom and the Costa Rican Human Development Story’, Oxford Development Studies, 33(3/4): 493-510.

(2006), The Capability Approach and the Praxis of Development, Basingstoke: Palgrave

Estado de la Nación (2008), Estado de la Nación en Desarrollo Humano Sostenible, San José: UNDP Costa Rica

Evans, Peter (2002), ‘Collective Capabilities, Culture and Amartya Sen’s Development as Freedom', Studies in Comparative International Development 37(2): 54-60.

Feldman, Shelley and Paul Gellert (2006), 'The Seductive Quality of Central Human Capabilities: Sociological Insights into Nussbaum and Sen’s Disagreement', Economy and Society, 35(3): 423-53.

Garnier et al. (1997), ‘Costa Rica: Social Development and Heterodox Adjustment’, in R. Jolly and S. Mehrotra (eds) Development with a Human Face, Oxford: Clarendon Press, pp. 355-83

Gasper, Des (2008), 'Denis Goulet and the project of development ethics: Choices in methodology, focus and organization', Journal of Human Development, 9(3):453-74.

Giddens, Anthony (1984), The Constitution of Society, Oxford: Blackwell (2004), Sociology (4 ${ }^{\text {th }}$ ed.), Cambridge: Polity

Goulet, Denis (2006), Development Ethics at Work: Explorations 1960-2002, London: Routledge

Heyer, J., R. Thorp and F. Stewart (eds), Group Behaviour and Development, Oxford: Oxford University Press

Kasser, Tim and Allen D. Kanner (eds) (2004), Psychology and Consumer Culture: The struggle for a good life in a materialistic world, Washington DC: American Psychological Association

Lauria-Santiago, Aldo (ed) (2004), Landscapes of Struggle: Politics, Society, and Community in El Salvador, Pittsburgh: University of Pittsburgh Press

Lukes, Stephen (2005), Power: A Radical View (2 ${ }^{\text {nd }}$ ed.), Basingstoke: Palgrave

McAdam, D., S. Tarrow and Ch. Tilly (2001), Dynamics of Contention, Cambridge: Cambridge University Press

Mesa-Lago, Carmelo (2000), 'Achieving and Sustaining Social Development with Limited Resources: The Experience of Costa Rica', in D. Ghai (ed.), Social Development and Public Policy: A Study of Some Successful Experiences, London: MacMillan, pp. 277-322.

Nussbaum, M. and A.K. Sen (1989), 'Internal Criticism and Indian Rationalist Traditions', in M. Krausz (ed.) Relativism: Interpretation and Confrontation, Notre Dame: University of Notre Dame Press

Nussbaum, M. (2000), Women and Human Development, Cambridge University Press (2004), 'Beyond the Social Contract', Oxford Development Studies, 12: 3-18

Offer, Avner (2006), The Challenge of Affluence, Oxford Clarendon Press

Qizilbash, Mozaffar (2002), 'Development, Common Foes and Shared Values', Review of Political Economy 14(4): 463-80.

Raz, Joseph (1999), Engaging Reason: On the Theory of Value and Action, Oxford: Oxford University Press (2003), The Practice of Value, Oxford: Oxford University Press

Rohan, Meg J. (2000), ‘A Rose by Any Name? The Values Construct', Personality and Social Psychology Review, 4(3): 255-277.

Rovira Mas, Jorge (2004), 'El Nuevo Estilo Nacional de Desarrollo de Costa Rica 1984-2003’, in M. FlórezEstraada and G. Hernández (eds), ¿Debe Costa Rica Aprobarlo? TLS con Estados Unidos, San José: Universidad de Costa Rica 
Sanchez-Ancochea, Diego (2005), 'Domestic capital, Civil Servants and the State: Costa Rica and the Dominican Republic under Globalization’, Journal for Latin American Studies, 37: 693-726

Sandel, Michael (2005), Public Philosophy: Essays on Morality in Politics, Harvard University Press

Schwartz, Shalom H. (1992), 'Universals in the Content and Structure of Values: Theoretical Advances and Empirical Tests in 20 Countries', in Advances in Experimental Psychology, 25: 1-65.

Sen, Amartya (1987), On Ethics and Economics, Oxford: Blackwell (1992), Inequality Re-Examined, Oxford Clarendon Press (1999a), Development as Freedom, New York: Knopf (1999b), 'Democracy as Universal Value’, Journal of Democracy, 10(3): 3-17. (2004), 'Elements of a Theory of Human Rights', Philosophy and Public Affairs, 32(4): 315-356.

Sieder, Rachel (2008), 'Underdevelopment and Development: Guatemala’, in P. Burnell and V. Randall (eds), Politics in the Developing World, Oxford: Oxford University Press

Stewart, Frances (2002), 'Dynamic Interactions Between the Macro-Environment, Development Thinking and Group Behaviour', in J. Heyer, R. Thorp and F. Stewart (eds), Group Behaviour and Development, Oxford: Oxford University Press, pp. 23-49. (2005), 'Groups and Capabilities’, Journal of Human Development, 6(2): 185-204.

Taylor, Charles (1995), 'Irreducibly Social Goods', in Ch. Taylor, Philosophical Arguments, Cambridge, Mass.: Harvard University Press, pp. 127-145.

Tilly, Charles (1998), Durable Inequality, Berkeley: California University Press

Verplanken, B. and R. Holland (2002), 'Motivated Decision-Making: Effects of Activation and Self-Centrality of Values on Choices and Behavior', Journal of Personality and Social Psychology, 82(3): 434-447.

WeD (2007), 'Wellbeing in International Development: Country Report Thailand', www.welldev.org.uk Wilson (1998), Costa Rica: Politics, Economics and Democracy, London: Lynne Rienner 